\title{
Responsibility: A case for the homeless in the City of Tshwane
}

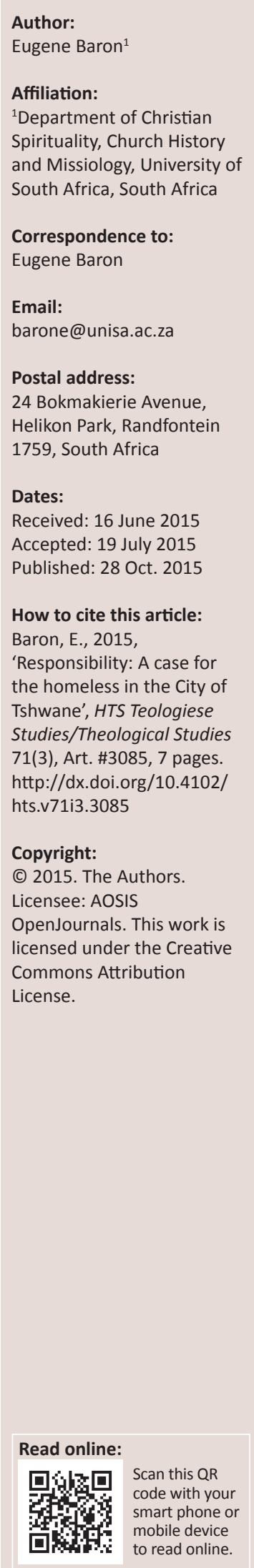

It is without doubt that the marginalised and destitute, such as homeless people, need all the help they can get to un-shackle them from poverty-stricken circumstances. Yet the reverse side of this is that marginalised, homeless people can become too dependent on such interventions, without taking responsibility for their future outcomes and consequences. The article reports on a contextual Bible study that was conducted with the homeless people in the city of Tshwane, specifically how they responded to the Lord's Prayer in Matthew 6:9-13. Bringing their responses in conversation with the voices of theologians, the themes emerging from the encounter are discussed. Bonhoeffer's theory of a responsible life is used as a theoretical framework. The author suggests that the homeless people as well as other relevant role players should take responsibility for the occurrence of homelessness in the city of Tshwane, South Africa, and offer solutions so as to eradicate this phenomenon in the future.

\section{Introduction}

When those in power speak of transformation and development within city centres, budgets are one of the first concerns of government, parastatals, non-governmental organisations and other stakeholders. The infrastructure, housing, and skills development (on which the most emphasis appears to be placed) are some of the items on the agenda of transformation and development. However, human capital - the most overlooked issue - and not material concerns should be the starting point on the list of priorities.

While conversations in governmental meetings go on with regard to the budgets, infrastructure and other material issues, South Africa is home to a melting-pot of diverse racial groups, cultures and ethnicities. This diversity became even more varied in the new democratic dispensation with an influx of destitute refugees making their way into South Africa in search of a better life. Every major city in the country is abode to a growing homeless population consisting of destitute South Africans - young and old - as well as economic refugees who have discovered that a better life in their country of refuge is only just a pipe dream. Embedded social inequalities, a legacy of colonisation and apartheid, continue to suppress a large number of people (Ramphele 2008). In addition, legislative corruption, maladministration and the refugee population explosion create situations that place an unbearable strain on the country's resources. As a result, homelessness, destitution, and other forms of vulnerability are pervasive.

Infrastructure and development are vital in addressing the plight of the homeless by providing housing for them and some kind of monetary relief. This research project suggests more than just the former; it raises the issue of responsibility in the context of homelessness. Even when everyone is mobilised, and resources utilised, the homeless should also participate and play an active role, and take some responsibility for the removal of the stigma attached to being homeless as well as the eradication of the phenomenon as it occurs in the streets of Tshwane.

The article starts off with a literature review on ethics of responsibility and how it relates to vulnerable people such as those who are homeless. In this regard the focus is on the work of Dietrich Bonhoeffer and his account on the ethics of responsibility. The discussion will be followed by a brief discussion on the methodology that was used during the research process. The author will then deal with the focus text during the contextual Bible studies with the homeless people on the Lord's Prayer by presenting the responses of the homeless, and subsequently a theological response to the text. Next, a discussion of the themes that emanate from the encounter follows. The purpose of the final discussion is to address the issue of the homeless people as primary agents for transforming their situation.

I want to start with a quote from Kauffman (1993:204): 'Act! Take responsibility for yourself! Take procession of your humanity! To become an agent is the primal task confronted by every person, a task presupposed by all others'. 
Conradie (2006:72-77) refers to a shift in moral reflection during the 20th century when the focus shifted from the freedom of the individual (the focus during the Renaissance and Enlightenment period) to do whatever they like without having to consider others, to a period during which some scholars agreed that people should take responsibility for their action and its future implications and consequences. Among those who followed this theory (responsibility) are: Max Weber, Dietrich Bonhoeffer, Hans Jonas, Paul Ricoeur, and Heinz Eduard Tödt. This kind of ethos is built on the notion that one needs to take the possible consequences and outcomes of one's own action into consideration, which therefore calls for an ethics of responsibility (Conradie 2006:76).

A good society - or good life, for that matter - will not fall from the sky; everyone has to take responsibility for their life, their actions, and be cautious of the future manifestation of their action(s). In respect of the homeless, there are many ways of approaching the aspect of agency, like focusing on their potential, their skills, and the good stories there are to tell from those who salvage themselves from the margins, but this is not the focus of the article. The author's main focus is not how to transform society or the act of 'forming new habits' (Baron 2014), but, even before engaging in the how (pointing to particular practices for homeless people to unshackle them from poverty-stricken circumstances), to take responsibility. The homeless are encouraged to take responsibility for the future good of the homeless people in the city of Tshwane. It will be daunting to focus on all the previously mentioned scholars (Max Weber, Dietrich Bonhoeffer, Hans Jonas, Paul Ricoeur and Heinz Eduard Tödt) who contributed to the notion of an ethics of responsibility. Hence, I will focus briefly on the contribution of Dietrich Bonhoeffer, especially his final work on ethics (see Green 2005).

In the chapter, 'History and good', in the momentous volume 6 entitled Ethics (Green 2005), Bonhoeffer focuses on what he calls a responsible life. Bonhoeffer (Green 2005:257) explains the structure of a responsible life as consisting of a 'bond to human beings and to God, and by the freedom of one's own life'. This bond that he refers to 'has the form of vicarious representative action in accordance with reality. Freedom exhibits itself in my accountability for my living and acting and in the venture of concrete decision' (Green 2005). He unpacks the notion of responsible life as described below.

A responsible life is one that is based on vicarious representative action. This means that a person is literally required to act on behalf of others together with those that they are in relationship. Bonhoeffer argues that human beings are in a relationship with each other, as Jesus Christ is to humanity. However, this vicarious representative action should be in accordance with reality, which means that one's actions should be in accordance with Christ's actions (Bonhoeffer 1959:263). Bonhoeffer states that only within Christ there is a good life.
According to Bonhoeffer (1959:269), responsibility 'is always in mutual relation between persons, derived from the responsibility of Jesus Christ for human beings, so that the origin, essence, and goal of all reality is the Real One, who is God in Jesus Christ'. Although the relationship is about human beings and God, it is out of this relationship that people should have a relationship to the world of things.

Furthermore, freedom finds expression in one's accountability, and in the venture of concrete decision. Bonhoeffer (1959:283) expresses the idea that responsible people act out of their own free will, considering all the existing circumstances, but 'observe, judge, weigh, decide, and act on their own'. He adds that '[f]ree action recognises itself ultimately as being God's action, decision as God's guidance ...' (1959:285).

Bonhoeffer (1959:293) also explains the place of responsibility; what we are responsible for, namely, our vocation. He argues that for Christians their life in Christ is their vocation. A Christian's vocation should permeate all the areas of their lives, and a response to the whole person, and reality as a whole. Christians should therefore not escape the world but, as he vehemently states, '... a stand against the world is taken within the world'. He explains that although one is called by God in one's vocation, which can be limited, our responsibility has no bounds. In sum, Bonhoeffer (Green 2005) asserts:

Thus in the given situation it is necessary to observe, weigh, evaluate, and to do all that with limited human understanding. We must have the courage to look into the immediate future; we must seriously consider the consequences of our actions; and we must attempt seriously to examine our own motives and our own hearts. (p. 263)

\section{Methodology}

In collaboration with the Tshwane Leadership Foundation ${ }^{1}$ and Potter's House ${ }^{2}$ (Centre for Women in Crisis), the Meal of Peace Community Engagement Project ${ }^{3}$ joined forces to work towards designing value-based interventions, rooted in biblical concepts of peace and justice, to address specific problems experienced by organised groups of homeless, marginalised, destitute and vulnerable people in the Tshwane city centre. After careful planning and consideration, the team developed a series of contextual Bible studies inspired by the biblical and theological community development work done by the Ujamaa Centre for Biblical and Theological Community Development at the University of KwaZuluNatal. ${ }^{4}$

\footnotetext{
1.Founded in 2003, the Tshwane Leadership Foundation is based in the Pretoria City Centre. The organisation works in partnership with churches and communities for urban transformation.

2.Established in 1993, the Potter's House is the first non-racial shelter for abused and destitute women in the city of Pretoria.

3.The Meal of Peace Community Engagement Project is an initiative of the Department of Christian Spirituality, Church History and Missiology, at the University of South Africa.

4.The Ujamaa Centre is a Biblical and Theological Research Institute housed at the University of KwaZulu-Natal.
} 
After the themes were drafted, each scholar went to the Tshwane Leadership Foundation (TLF) and facilitated discussions around the themes, by using a particular Bible text. The text that was used during this research project was the account of Matthew on the Lord's Prayer. The text, Matthew 6:9-13, was read:

Pray like this: Our Father who art in heaven. Hallowed be thy name. Thy Kingdom come. Thy will be done, on earth as it is in heaven. Give us this day our daily bread. And forgive us our debts as we also forgive our debtors. And lead us not into temptation, but deliver us from evil.

The homeless people were then given the opportunity to share their understanding of the text, and what it meant in their own context, as homeless people in the Tshwane city centre. On many occasions, participants chose to present their responses in veiled language so as to protect themselves. This reflected the extreme vulnerability of this group and the possibility that among the participants there could be both victims and perpetrators of some of the crimes and injustices they referred to in their responses. The most significant point, driven home acutely, was that all participants were victims of the country's social, political and economic situation.

I did my own research on the scholarly interpretation of the text, and will discuss it after the next section, which entails the responses of the homeless people. After these two accounts (the homeless people's responses, and the scholarly interpretation of the text) the themes that emerged from the encounter with the homeless people will be discussed.

\section{Responses from the homeless group}

After Matthew 6:9-13 was read, the homeless people were given the opportunity to share their understanding of the text, and what it meant for their own context. From the outset, it was clear that participants showed great respect and reverence for the Bible. They felt that they could rely on God and that poverty and deprivation were not the will of God. They believed that they were battling an evil that was working against God's will for their lives. The Bible study provided them with the opportunity to read the Bible in the light of their own experiences.

The participants noted that homelessness and marginalisation were the result of systemic corruption, exploitation, maladministration and greed. Homelessness and marginalisation are largely perpetuated not because people are lazy or do not want to work, but are created by a system that entrenches poverty and vulnerability for the majority of people in South Africa. One of the participants responded to the so called 'laziness' stigma attached to them by responding:

'Me, I am a hustler. I hustle for a living. I get up early. I put my blanket in a box and leave it under the bridge then I start my day, hustling for only just some food for me to eat now because I am hungry. I work hard to get that food. Sometimes I take my bucket and stand at the robot, and then I wash the car windows. Sometimes these rich people, they scream at me to go away.
Sometimes they give me bread or a few cents to buy something. Then I have to work hard again, to hustle again for something. I do like this for the whole day, doing different things, I work very hard, and then I go to find my blanket under the bridge to sleep in the cold.'

The participants recognised their weakness, like any other person, and responded to the text, '... lead us not into temptation ...', pointing to their confrontation on a daily basis with various temptations that sometimes result in succumbing to the moments to do evil and get involved in unacceptable behaviour. They spoke about the 'dark side' of life on the streets and how the streets are riddled with opportunistic drug dealers, pimps, loan sharks and other dangerous temptations. They raised their voices at the powerful - and how the vulnerable and marginalised, the homeless people, are at their mercy. It did not all end with their helpless fate being at the mercy of the powerful, but the participants believed that the best way for them to deal with life is to stick together and get involved with organisations like Tshwane Leadership Foundation and Potter's House where they can find assistance. Drug activities are not the only temptations that the homeless people of Tshwane reported; they also highlighted the dangers of sexual predators on the streets:

'No one is safe. Old women, young boys, young girls, they are all victims here. They get raped, they get murdered, they get beaten up and nobody cares. Sometimes it's because they go out because they need money, so they sell themselves to rich men in nice cars but other times, they are kidnapped for the whole weekend sometimes and these wicked people rape them and then just throw them out as if they are rubbish [...] I want to tell you a story about a boy who was not even homeless. He was wearing nice clothes and nice shoes and walking here down in Van der Walt [Street]. He saw a nice car was following him, then the man said, get in, I can see you like nice things; I can give you many nice things. Get in. The boy was tempted but he thought, what do they want to do with a boy? They want to have sex with me. So he ran away and the people in the car, they chased him for a little while then they just leave him alone. It's true, on the streets, young boys who are not even gay, they will go with these rich men so that they can get those nice things. It happens all the time.'

They also responded to the salient hope that the text provides: that it is God's will that every human being has a place to call home, enough food to eat, to be free of debt, and to live happy lives. As they read and interpreted the text together, they believed that God was exhorting them not to give up. The text inspired them to use both 'their faith' and 'action' to serve as a remedy for their dire situation. They also noted that often when people are faced with such dire situations they become despondent. They believed, however, that getting despondent is not going to get them anywhere, but understood that the text was indeed challenging them not to just sit around and wait for things to happen, but to go out and use what God has given them, hands, eyes, feet, ears, talents, their unique type of personalities, and whatever they have, to improve their lives. They stated that the poor cannot rely on the rich to solve the problems of the poor, because the rich have proved throughout history, to be selfish and 
self-seeking. They stated that all they wanted was for the rich and powerful to notice them, to see what they are capable of and to partner with them to improve their situations. One participant commented, 'We are willing to work hard, we only need to be given a chance in life.'

The participants noted that in order for the Kingdom of God to be realised in their contexts (in reference to the part of the text, '... let your Kingdom come ...'), they should not be bitter and filled with hatred towards the rich and powerful, but ought to forgive and attempt to create opportunities to work together. The group believed that because they do not have money and the preoccupations that come along with being wealthy, they have more time and opportunity to spend time in prayer, because they rely on God for every moment of their lives. It is therefore their duty to assess situations and understand that the rich too are slaves; the only difference is that the poor are slaves to poverty and the rich are slaves to money. The participants believed that between the lines of the text was the message that the Kingdom of God needs to be realised for both rich and poor. Those who are trapped in the sin of greed, exploitation and corruption need to be delivered from their lot, become more human and live happy and healthy lives. Just like the poor and exploited, they deserve to live happy and healthy lives. Their understanding of the coming of the Kingdom of God on earth means a time when there is peace and no suffering.

\section{Response from theological scholars}

When the text in Matthew 6:9-13 is read through the lens of theological scholars it has slightly different nuances as compared to the understanding of the homeless people. The Lord's Prayer forms part of the Sermon on the Mount. It is part of Jesus' teaching to his disciples in response to their question: How must we pray? Various scholars agree with the structure of Combrink (2008:68) that the Lord's Prayer comprises three sections: the first section is the address (appellation), the second comprises the three 'thou' petitions (9b-10) 'directed to God' (MacArthur 2006:1371), and the third section comprises the three 'our' (11-13) petitions, and is directed 'toward human needs' (MacArthur 2006:1371).

According to Combrink (2008), the first three 'thy' petitions have to do with the disciples' prayer to God for the realisation of their calling. Combrink interprets this section as the children of God who await an action from God (although an act on the part of the intercessors is not excluded). The second three 'our' petitions, however, are directed to God about what the disciples need to accomplish as their task on earth.

Besides the structure of the text, the lenses through which the text is read also need to be briefly discussed. According to the consulted literature there are at least three perspectives. There are those interpreters who believe that the text should be read through an eschatological lens (referring to the coming of the Lord on the Last Day). Meier (1980:61) and Morris (1992:142) support this paradigm. They substantiate their claim by referring to the phrase 'Your kingdom come' which they assert, makes the 'Our Father' an 'eschatological prayer and a prayer that God will hasten the end-time'. This 'endtime' according to Meier (1980:61) refers to the 'appearing of God on the Last Day'. The eschatological vision and its climax will find expression in the death-resurrection of Jesus, which serves as the 'turning of all ages' (Meier 1980:61).

Then there are those who view the prayer as being relevant to the present day. Mounce (1985:56) prefers that the text be read for the present, as well as the future (eschatological). In similar vein Koopman (2014) makes use of a more contextual reading of the text. In collaboration with other colleagues, he reflected on the Lord's Prayer which served as Pentecost sermons for the Dutch Reformed Church family during the season of Pentecost in 2014. The series was entitled, 'Cries for a humane life'. He contextualised the prayer, and reflected on it as a prayer that is relevant for present challenges.

The lens through which the text is read will directly influence the meanings and interpretations of the text; therefore, the lens is important before engaging in any interpretation. For instance, these two approaches (contextual, eschatological) will yield different results, especially in terms of comments on two parts of the Lord's Prayer, '... your Kingdom come ...', and '... give us today our daily bread ...'. I will follow Koopman's cue and interpret the text through a 'contextual' lens, addressing the plight and the cry of the homeless people in the city of Tshwane. In addition, I will follow the three-section structure proposed by Combrink (2008).

\section{The appellation}

There are three phrases that need to be discussed as part of the address: the 'Our' in 'Our Father', the metaphor for God as 'Father' and the reference 'in heaven'.

\section{'Our ...'}

Koopman (2014) interprets the 'Our' in the 'Our Father' in his series, 'Cries for a humane life', referring to many people across the world that are lonely and '... have no sense of belonging, Ubuntu, community ...' That is exactly what Morris (1992:144) points out when he argues that people who are praying 'Our' are by doing so actually making themselves part of this 'Our' community. This prayer therefore, '... delivers the lonely, the excluded, and the marginalised from the separation they experience ...' (cf. Hauerwas 2006:77).

\section{'... Father ...'}

Koopman (2014) argues that the 'Father' metaphor speaks especially to those who are fatherless, motherless, and parentless. It does not refer to any father, but a 'heavenly' father, one that does not give the intercessor 'hell'. This father, to whom the intercessor calls, connects all those who call to God as their father (Scheck 2008:87); therefore, all those who might be fatherless, motherless, and parentless, 
after calling God father, become 'sons' (of the father), part of the community and sharing in $u b u n t u$. In a similar vein Meier (1980:60) argues that the 'Our' in the 'Our Father' presents Christians not as 'isolated individuals' but as 'members of the church'. Combrink (2008:68) points out that the designation of God as father was not well known in the Old Testament; therefore, this became a central moment in the early church, where they could be introduced as children of God, who serves as their father.

\section{'... who art in heaven ...'}

Often God as father is compared with all earthly fathers. Hauerwas (2006:76) makes an important point in this regard: we do not call God 'Father' because of our experience with earthly fathers; however, all human fathers must be judged and measured by the relationship of the Son (Jesus Christ) to the Father.

\section{The 'Thy' petitions}

As previously pointed out, the three 'Thy' petitions concern God: the first is ' ... hallowed be Thy name ...'; the second, '... Thy Kingdom come ...'; and the third, '... Thy will be done ...', followed by '... on earth as it is in heaven ...'

\section{'... hallowed be Thy name ...'}

To 'hallow God's name,' according to Hauerwas (2006), means:

... to do so as commanded by God, sanctified, set apart, ordained, made holy. We are commissioned by God to live lives that make visible to the world that the Holy God, the same God before whom Moses hid his face when he was told God's name (Exod 3:6), reigns. God the father has redeemed his creation through His son. God has regained his territory from the enemy. God's newly won territory is those who pray, 'Hallowed be thy name'. (pp. 77-78)

For Combrink (2008:69), the part 'hallowed be Thy name ...' points to the fact that the disciples of Jesus will fulfil their calling in such a way that the people will glorify him, and bring honour to his name.

\section{'... Thy kingdom come ...'}

These people of God who pray '... Thy Kingdom come...', pray 'for an end to the kingdoms of this world, dominated by $\sin$ and the power of death' (Hauerwas 2006:78). To pray this, Hauerwas states, is to pray for 'disruption' (when we pray for the Kingdom of God to continue). According to Scheck (2008), when someone asks for the Kingdom to come

$[h]$ is either asking for the entire world in a general sense, that the devil will cease to reign in the world, or he is asking that God would reign in each one, and that sin would not reign in man's mortal body. (p. 87)

But he cautions that those who request this, should have great confidence and a pure conscience to ask for the Kingdom of God to come, and should not fear the judgement (referring to the final judgement on the Last Day).
Morris (1992:145) argues that 'Thy Kingdom come' requests 'God to take action, not for worshippers to bring the Kingdom into being'. Filson (1960:96) says that if the 'Kingdom comes' it will mean 'security for all good, exclusion of all evil, and privilege for all who share the blessings of their father's gracious sovereign rule'.

\section{'... thy will be done... on earth as it is in heaven ...'}

The will of God, which finds expression in the life of Jesus, should be prayed for, especially in the context of personal selfish wills. Hauerwas (2006) says that it is indeed

[o]ur wills, the will of the world' that nailed Jesus to the cross, but that 'God defeated our wilfulness, making it possible for us to pray that God's will be done on earth. (p. 78)

Morris (1992) comments:

The prayer looks for the perfect accomplishment of what God wills, and that in the deeds of those he has created as well as in what he does himself. It points to no passive acquiescence but to an active identification of the worshipper with the working out of the divine; if we pray that way we must live that way. (p. 145)

\section{The 'Our' petitions}

Filson (1960:96) says that this second part refers to the 'needs of the disciples, desires and struggles. Disciples may pray for God's help in every aspect of their lives'. He further asserts, 'The disciples may pray for bread, food to sustain life, provision for their physical needs; bread not for far-off future needs, but for the coming day.'

\section{'... give us today our daily bread ...'}

Morris (1992:146) points out that immediately after the 'perfect establishment of the Kingdom of heaven and the accomplishment of the will of God we have a prayer for bread'. Morris (1992:78) cautions that the request for bread needs to be taken seriously as also a call for the provision of physical needs and not for the 'indefinite future'. Bonhoeffer (1959:167) also makes an important remark: the disciples are told to 'ask for bread not only for themselves but for all men on the earth, bread really comes down from above as the gift of God alone'.

\section{'... and forgive us our trespasses, as we forgive those who trespass against us ...'}

Hauerwas (2006:79) points out that ' $[t]$ he prayer also requests that we must learn that we are the forgiven ... to recognise that our life is a gift'. Koopman (2014) writes in this regard: '... where his children are thus embraced with forgiveness, our hearts inevitably open up to forgive others'.

\section{'... and lead us not into temptation, but deliver us from evil ...'}

Mounce (1985:57-58) argues that the Greek can be translated as 'evil' or 'the evil one'. However, he says that because in Hebrew thought Satan is not designated as the evil one, many interpreters prefer the word 'evil' which refers to those difficult circumstances that often plague our lives (cf. Morris 
1992:149). Hauerwas (2006:79) argues that to pray with Jesus the 'Our Father' 'is to become part of his struggle with the powers of this world'.

\section{Discussion}

The convergence of the two perspectives - the understanding of the homeless people of the Lord's Prayer, and also those of theologians - brought about some interesting themes that need some discussion. Although there might be other themes that should be included in the discussion, when studying these two interpretations, I picked up a few themes, which I consider as valuable insight for the discourse on homelessness.

The homeless people's experience of some sort of struggle (of forces), which they see as 'the struggle between the rich and the poor' at play in the world is noted. This struggle, according to them will be dealt with by removing the 'evil' from both rich and poor, and only thereafter there might be chances of prosperity in the lives of the homeless people. This is seen also in the way theologians interpret the insertion 'deliver us from evil', which they interpret as not only referring to 'the evil one', but also 'evil'. The pervasive 'evil' in the world, where the gap between the rich and the poor becomes wider, is a grave concern in a city like Tshwane. Means should be sought to close this gap, by, for instance, providing a good welfare system that guarantees every South African a sustainable life.

The articulation of shared interest and shared responsibility emerged as one of the themes that runs like a thread through the engagement with the homeless as well as through listening to the responses from theologians and their understanding of the text. The 'Our' as part of the 'Our Father' is articulated by the homeless people - as how they want to see them - co-responsible for the dire situation of homelessness in the city of Tshwane. Theologians point out in their comments, that at least this prayer is bringing the lonely, the excluded, in communion with other children of God, to make a concerted effort to address their father, on issues that need his attention. Those who pray this prayer, whether rich or poor, are praying for the same needs, and well-being for all God's children.

This 'co-responsibility' referred to by the homeless people in the city of Tshwane is well captured by De Beer (2008) who dealt with this in his article on the need for the personal and collective recovery of dignity and agency and the need for communal solidarity. De Beer showed that in the new democratic dispensation, new silences condemn people to exclusion, indignity and death in the same way that silences under apartheid condemned people before 1994. Between the lines of De Beer's article is the echo of the sentiments of the contextual Bible studies participants, namely that to be silent in the face of the suffering of fellow human beings is to be complicit in your own dehumanisation. A concerted effort must be made to resist the new silences of our time, the silences that lead to violence against the landless and the poor, the silences that lead to the destitution, rape and violation of women and children, the silences that lead to our own dehumanisation. The homeless people which form part of the 'Our' in the Lord's Prayer, despite the exclusion of participation in conversation regarding their plight and situation, are given a voice by God, not only in the sense of speaking to God, but also voicing their plight to God for the fulfilment, and realisations of their physical, material ('... daily bread ...') needs on earth.

It is not only the issue of co-responsibility that emerged through the engagement with the homeless people, but also a particular focus on the homeless people's personal responsibility for their future outcomes and consequences. Their response, to use their skills for the betterment of the homeless situation in Tshwane, which is complemented by how theologians articulate the 'permission' through the last three 'our' petitions, to pray for their 'physical, material needs', also speaks to their homeless situation. It is in this light, of personal responsibility, that I want to bring in the discussion of Bonhoeffer on responsibility as part of the broader discussion in the context of homelessness.

Bonhoeffer's comments on discipleship are highly appropriate in light of the scripture concerning the Lord's Prayer; a prayer Jesus taught to his disciples. The life of a responsible person does indeed come from a relationship with God and others, as both Bonhoeffer and the theologians' interpretation of the text suggest. The same notion found expression in the way the homeless people spoke about their responsibility to do something, and to 'show them' (referring to those who are powerful and those who stigmatise them as being lazy) that they take responsibility for the betterment of their lives.

Responsibility for Bonhoeffer means to be in a relationship with God and others. This is important especially as the homeless people are often seen as the only ones that carry responsibility for the homeless situation in the city of Tshwane. Hence, in the scholarly interpretation of the text, those who address God as father are deeply connected to each other, and are crying (in Koopman's terms) alongside one another. It is here where I especially believe that multiple disciplines, organisations with different emphases and approaches should take responsibility for future consequence and outcomes for the homeless situation in the city of Tshwane. Government cannot be silent either, but has a co-responsibility to provide housing, as per legislation, and thus fulfil their responsibility.

\section{Conclusion}

In concluding, we are confronted with some pertinent questions: What do we make of the responses of the homeless people? Does their opinion count? Do we in any way have to take them seriously? The answer is unequivocally: Yes indeed, their contribution certainly counts. The prayer that Jesus taught his disciples in Matthew 6:9-13 at least suggests an opportunity to raise one's concerns to a father who makes 
one part of a family of all those who confess God as father. Therefore, the homeless people are indeed not without a family; moreover, they are given a voice, together with all other voices that 'struggle' and have other 'evils' against which they need to actively engage - taking responsibility for unshackling them.

It is not enough to examine the experiences of homeless people, the marginalised and the destitute, and it is not enough to write about their plight. However, in order to address the phenomenon of homelessness and marginalisation in South Africa, someone needs to take responsibility. We need to recognise that failure to act - failure to commit to a process that will lead to peace and justice for all - is failure to be human

It is recommended that in training, education, or any form of intervention to the vulnerable and the marginalised, there should be enough room for them to reflect on their responsibility to alter the dire circumstances in which they find themselves. Without exonerating the government and non-governmental organisations, or playing down their role, it must be stated that the vulnerable should in some way or other take up their responsibility to change their own future and create their own tomorrow, without waiting for others to step in.

Finally, I cannot at the time of the contextual Bible study recall of any incident where there were homeless people who did not subscribe to the Christian message. However, this remains a possibility, because not all homeless people in South Africa or abroad can be presumed to be Christians. The methodology allowed the homeless (whether Christian or not) to analyse their situation in the light of the Lord's Prayer in Matthew 6:9-13. Hence, the question arises, what would the responses of homeless people be should they not subscribe to the biblical message and the response of Bonhoeffer? I would argue, the situation (homelessness) would still require from them to take responsibility; granted, not because of any Christian conviction, or the underlying narrative of Jesus, but solely because they believe in being change agents, and take responsibility for the betterment of their own lives. Bonhoeffer, who writes on an ethic of responsibility in the context of Nazi-Germany, does not only serve as a remedy for Christians faced with societal challenges, but is also relevant and applicable to non-Christians. His notion of responsibility is based fundamentally on a relationship with God and others, which indeed also includes all religious convictions.

\section{Acknowledgements Competing interests}

The author declares that he has no financial or personal relationships which may have inappropriately influenced him in writing this article.

\section{References}

Baron, E., 2014, 'Forming good habits: A case for the homeless in the city of Tshwane', Missionalia 42(1/2), 134-146. http://dx.doi.org/10.7832/42-1-2-52

Bonhoeffer, D., 1959, The cost of discipleship, SCM Press, New York, NY.

Combrink, H.J.B., 2008, Skrifuitleg vir Bybelstudent en gemeente: Die evangelie volgens Matteus, NG Kerk Uitgewers, Wellington.

Conradie, E., 2006, Morality as a way of life: A first introduction to ethical theory, Sun Press, Stellenbosch.

De Beer, S., 2008, "'Taking back our streets": Reading Steve Biko's Black consciousness and the quest for true humanity on the streets of Tshwane', in C.W. du Toit (ed.) The legacy of Stephen Bantu Biko: Theological challenges, pp. 169-197, Research Institute for Theology and Religion, University of South Africa, Pretoria.

Filson, F.V., 1960, A commentary on the Gospel according to St. Matthew, Adam \& Charles Black, London.

Green, C.J. (ed.), 2005, Dietrich Bonhoeffer works, vol. 6: Ethics, Fortress Press, Minneapolis, MN.

Hauerwas, S., 2006, Matthew, Brazos Press, Grand Rapids, MI.

Kauffman, S., 1993, Origins of order: Self-organization and selection in evolution, Oxford University Press, Oxford.

Koopman, N.N., 2014, Cries for a humane life: Reflections on the Lord's Prayer, Bybelmedia, Wellington.

MacArthur, J., 2006, The MacArthur Study Bible, Thomas Nelson, Nashville, TN

Meier, J.P., 1980, Matthew, Veritas Publications, Dublin.

Morris, L., 1992, The Gospel according to Matthew, Eerdmans, Grand Rapids, MI.

Mounce, R.H., 1985, Matthew, New international Bible commentary, Hendrickson Publishers, Peabody, MA.

Ramphele, M., 2008, Laying ghosts to rest: Dilemmas of the transformation in South Africa, NB Publishers, Cape Town.

Scheck, T.P., 2008, St. Jerome: Commentary on Matthew, The Fathers of the Church series, Catholic University of America Press, Washington, DC 